\title{
THE MIND OF GOD
}

\section{COLIN MCGINN}

\begin{abstract}
A radically dualist view of the relationship between God and the universe is apt to make the problem of Divine intervention more difficult than under other metaphysical conceptions. We need to find a closer relationship than this if the causal picture is to work. We could try saying that God is realized by the universe, without being reducible to the universe. He has no further substance over and above that of the universe, but he is not simply identical to the universe (I suppose this would qualify as a type of pantheism). I am not sure I know what this idea of realization comes to for the case of God and the universe, but it least it promises to make it feasible for God to be enmeshed in the natural causal order, without collapsing into it. It is not so much that God intervenes as supervenes, to use the jargon. On this picture, there is a megauniverse that includes both the physical universe and God, with the two locked somehow together.
\end{abstract}

\section{DIVINE PSYCHOLOGY}

A typical university education in the science of psychology will include a course entitled 'comparative psychology', which deals with animal psychology and its similarities to, and differences from, human psychology. But I have never heard of a psychology degree that offers a comparative psychology course on divine psychology and its relation to human and animal psychology. Yet God must have a psychology, because he has a mind. And there must be a philosophy of mind appropriate to the divine mind too. God has various mental faculties, and these must have a nature and a modus operandi. There must be a way that God's mind is. So why can't we study the mind of God? Why do we find this gap in the curriculum? 
It can hardly be that the subject is deemed unacceptably impious, because theology studies God in all sorts of ways - so can't he be studied psychologically? If we can discuss God's plans and intentions, then he must have plans and intentions; and then we can ask theoretical questions about these divine mental attributes. Any being with states of mind must have a psychology in which those states feature. It might be agreed that God has a psychology, but denied that we can study it, because we can't do experiments on God or observe his behaviour. We therefore cannot have a proper empirical science of God's mind. It is no doubt true that we can't use God as an experimental subject, along with the usual herd of conscripted undergraduate subjects, because of his general unavailability; but it is wrong to conclude from this that we cannot meaningfully investigate God's mind. We cannot perform experiments on Shakespeare either (or any other dead person) but that doesn't mean that we can't make justified statements about the mind of Shakespeare. Why? Because we know quite a lot about Shakespeare's mind from the evidence of it he left behind, as well as from his membership in the human race, and from that we can make reasonable inferences. Experimental evidence is not the only kind of psychological evidence there is. So we might have enough information about God that we can make sensible inferences about the nature of his mind. The right thing to do is look and see.

Another objection to the project of divine psychology might be made: we cannot have a psychological theory of God's mind because God does not exist. It would be like having a comparative psychology that included the unicorn - a nonexistent beast with a nonexistent mind. But this is a bad argument: we can ask about the mind of Sherlock Holmes without presupposing that he exists. Fictional characters have minds too, and hence psychologies. Thus we know that Holmes has a very high IQ, is easily bored, and is subject to narcotic cravings. We also know that he has a language faculty and hence must have acquired language during childhood, with all the psychological machinery that that implies. Even if God is merely a fictional character, with no existence, we can still ask what kind of psychology he has. The evidence for this will come from human intentionality - how God has been depicted and conceived in various traditions of religious thought. God (the fictional character) must have a psychology that is such that those depictions could hold of him - just as with Sherlock Holmes and other fictional characters. If God exists, on the other hand, then his mind also exists, and hence has an existent nature - which can in principle be investigated. Our knowledge here can 
only be tentative, to be sure, but that is true of large tracts of human knowledge in general. ${ }^{1}$

So there seems no objection of principle to pursuing the subject of divine psychology, though it might prove arduous and elusive. Our approach will naturally be comparative: how does divine psychology compare to human psychology? I will be unavoidably sketchy about this in what follows, but I think the outlines of the divine mind are fairly clear. Two points seem clear at the outset: God thinks and has mastery of language. Just as we are essentially thinking things, as Descartes claimed, so God is essentially a thinking thing - a res cogitans. God has reason, and plenty of it. ${ }^{2}$ This means that God thinks logically - his thoughts are governed by relations of logical validity. If so, his thoughts must have propositional content - since there is no other kind of logical thought. We must ascribe thoughts to him using 'that'-clauses: God thinks, for instance, that man is weak and easily led. God reasons according to modus ponens and other logical rules, which concern propositions. In this he resembles humans, cognitively speaking. ${ }^{3}$ God respects the laws of logic and conforms his thought to them.

But his propositional thought differs in one important way from that of humans: his thought does not generate opaque contexts, on account of his omniscience. A human can believe that Hesperus is a planet without believing that Phosphorus is a planet, even though Hesperus is identical

${ }^{1}$ It is often supposed that human knowledge of the mind of God is necessarily limited - that God must be mysterious to us. Yet it is also believed that we can know quite a bit about God's wishes and intentions, and his intellectual faculties. This mixture of ignorance and knowledge is not, however, unique to God, but applies to all minds, and even to the physical world. It is not that God is uniquely impenetrable.

${ }^{2}$ One thing God has plenty of is knowledge, on account of his omniscience. But it is a question what form this knowledge takes. Presumably he has propositional knowledge (knowledge that $p$ ), but he must also have knowledge how and knowledge of. Is his propositional knowledge a type of belief? Does he have justification for what he believes? Is it a priori or a posteriori? Does he have introspective knowledge? Is his knowledge analyzable? These are all good questions, but I won't be discussing them here, since I am concerned with God's psychology rather than his epistemology.

${ }^{3}$ I don't mean that, like humans, he reasons in time, slowly or quickly, smoothly or falteringly. But he must apprehend logical relations between propositions, possibly 'at a glance. His superiority to humans as a logical thinker does not mean that he is not himself a logical thinker. (Perhaps I should note here that I am assuming God to be an entity more person-like than, say, some sort of impersonal force - that is, I am following the precepts of the main world religions. If God is conceived impersonally, then of course we cannot ascribe the attributes of a person to him (or 'it').) 
to Phosphorus, because he or she doesn't realize that the identity holds that crucial piece of knowledge is missing. But God knows everything, necessarily so, and therefore he cannot fail to know the truth of all identity statements. So all ascriptions to God of singular thoughts will produce only transparent contexts, in which co-denoting names are intersubstitutable. God's thoughts no doubt have sense and reference, as Frege argued, but God recognizes the referential coincidence of all senses that in fact have the same reference. God knows every mode of presentation of every object, so he cannot fail to know the truth of every true identity proposition. ${ }^{4}$

Given that God thinks in propositions, various other things will follow, very familiar to philosophers. The thoughts of God will have logical form, possibly that specified by standard predicate logic. When God has a descriptive thought (say, 'The queen of England has been a good monarch') his thought has the logical form captured in Russell's theory of descriptions (a quantified conjunction). His general thoughts will have the structure specified in Frege's account of quantification, since this is by common consent the correct theory of generality. His adverbial thoughts will conform to Davidson's theory of adverbs - or whatever is the best theory of adverbs. The content of God's thoughts will include particular objects and not merely general concepts - granted the correctness of 'direct-reference' theories of thought. These theories are not held to be merely contingently true of humans, but to apply to all beings capable of the thoughts in question - and hence to God's thoughts. They are theories of the essence of propositions. ${ }^{5}$

God's putative mastery of language ('In the beginning was the Word, and the Word was with God, and the Word was God') will also imply various theses about his psychology. As we know from Chomsky and others, language is a recursive structure, based on a finite vocabulary, with finitely many grammatical rules. God's language (maybe it is

${ }^{4}$ If Frege is right, God apprehends objects under modes of presentation, not 'directly', so that his thoughts are perspectival, like ours - they represent the object under a certain specific aspect. It is just that God always knows when two senses correspond to the same reference, so that he can never be surprised by a true identity statement. Hence there is no referential opacity in ascriptions of propositional attitudes to God.

${ }^{5}$ It is like God's mathematical concepts: he thinks of number according to the theory developed in Principia Mathematica (or whatever the best theory of numbers is). The correct analysis of the concept of number applies to anyone employing that concept, human, Martian, or divine - because the analysis tells us what number is. 
mainly a language of thought, not much used for communication) may not share the precise rules and vocabulary of human languages, but it must still exhibit syntactic and semantic structure. It must be compositional, generative, and imbued with grammatical rules. It cannot be systematically ungrammatical! It must be based on rules that produce sense not nonsense. Thus God's language faculty has a structure very similar to the human language faculty, at least at an abstract level: a finitely based recursive system of normative rules. Much the same is true of his cognitive capacity: his thoughts too must result from rulegoverned combinations of conceptual elements. We can therefore say that this aspect of God's mind has the architecture of systems with 'discrete infinity': words and concepts are discrete entities that can combine into infinitely many complex sentences or thoughts. The divine mind is 'digital' not 'analogue'.

I would say that this kind of cognitive architecture also applies to God's geometrical and social modes of cognition. In both cases we have primitive elements (shapes or individual people) that combine into novel complexes according to fixed rules. When God thinks about human beings in groups, say, his thoughts exhibit the same abstract schematism: he represents us as a social formation made up of individuals that may combine in all sorts of ways and with certain sorts of outcome. How else could he think about entities that exhibit the combinatorial character we find in social groups? And the same holds for his geometric representations of the world. If entities are compounded from other entities in law-governed ways, then any adequate conception of those entities will reflect their internal structure, of necessity.

I think we can also assert that God is conscious. There is something it is like to be him, even if we cannot grasp it (compare the bats). On some views, this implies that God harbours 'qualia' in his mind. On other views, every divine conscious state must exhibit intentionality, this being the 'mark of the mental' (Brentano). He must also be self-conscious, much like us. And he must have a self - and not just be a mere bundle of sensations or thoughts. His consciousness must be unified, centred. He must refer to himself with the first person 'I' and ascribe conscious states to the self thus referred to, incorrigibly so. These 'I'-thoughts will have the features of all such thoughts, involving immunity to error through misidentification, as well as something like David Kaplan's distinction between character and content. For these are logical features of ' $\mathrm{I}$ ' and 
apply to any user of that word. ${ }^{6}$

One respect in which the consciousness of God differs from our consciousness (and that of other animals) is that there is no mind-body problem for God. This is simply because he has neither body nor brain. Thus there is no mystery in God's nature stemming from this problem: we don't face a deep puzzle about how the consciousness of God could result from neural activity in God's brain. God's consciousness, unlike ours, does not emerge from brain activity; nor does it evolve from more primitive biological forms. How it does come about is another question, but it certainly doesn't arise from electro-chemical activity in a galaxy-sized divine brain. In this respect, then, God's consciousness is less mysterious than ours. It is true that some philosophers have argued that the notion of a disembodied consciousness is not logically coherent, but the idea of an embodied consciousness also presents deep mysteries. God exhibits no mysterious psychophysical link or dependence. His mind is not a mysterious emergent. ${ }^{7}$

God also possesses a will. He decides, has practical reason, and he deliberates. ${ }^{8}$ But is his will free? Everyone knows what a problem this is in the case of humans. The only thing I wish to say about the problem here is that it applies equally to God. Freedom seems to be compatible with neither determinism nor indeterminism, but these exhaust the possibilities, so the will is not free. But God's decisions are subject to the same dilemma, even if he is not constrained by the physical world:

${ }^{6} \mathrm{I}$ assume monotheism in this paper, but the same general points apply under polytheism. The Greek gods, say, will each have mastery of the word 'I', and this word will have a uniform meaning for all of them - and hence the same logical properties. The same logic applies to every thinking being.

7 This is not to say that there is no mystery about the origin of God's mind - just no mystery about how it could originate in matter (since it doesn't). It might have existed for all eternity in its present fully developed form, or it might have originated in some prior divine reality not of its present form. According to the latter hypothesis, God's mind arose from a proto divine substance (if that is the word) that became organized into a full-fledged divine mind. First, there was a primitive divine reality, not yet organized into an actual functioning mind; and then something happened to bring about God's mind, as it now exists.

${ }^{8}$ Again, we need not suppose that God deliberates in time: yet he comes to conclusions, both theoretical and practical, by means of his faculty of reason. How this is possible is, admittedly, something of a mystery - is it to be conceived of as instantaneous or does the concept of time not apply to it at all? In any case, God has plans that he carries out intentionally. 
if his acts of will are caused, they cannot be free; but they cannot be free if they are not caused either, for then they will be random (quantum indeterminacy at the divine level will not save God's free will). There are, of course, many attempts to get around this argument, which I cannot discuss here (I have one myself); ${ }^{9}$ but I think it is fair to report that none are free of difficulty. In any case, free or not, God has a will - he is not purely contemplative or passive. Given that God has a will, he must also have desires and wishes: not for food and sex, to be sure, but for peace, harmony, and goodness. When God acts he acts for reasons, and these reasons comprise beliefs and desires in the usual bipartite way. If God sent his son into the world in order to be our salvation, then he must have desired our salvation and believed that by sending his son he could satisfy that desire. So God has a belief-desire practical psychology: he has desires for certain ends and beliefs about the means for achieving those ends, and he forms intentions by combining his desires and beliefs. Maybe he even has degrees of desire, so that these psychological states are subject to continuous magnitudes - as when we speak of having a strong desire for immortality. Then God's mind would be discrete in some ways (words and concepts) and continuous in others (degrees of desire) - just like ours, in fact, but with a rather different desire set. Presumably God does not work with subjective probabilities in his practical reasoning, given his omniscience, but he still functions according to standard belief-desire psychology, since he acts for reasons. ${ }^{10}$

I don't think that God has an unconscious or that he dreams. He certainly does not have a Freudian unconscious (as I doubt that humans do), but he also lacks the kind of cognitive unconscious modern psychology attributes to us. There is no subconscious informationprocessing going on in God, so as to save on the amount of conscious space being taken up - God has no such computational limitations. In God's mind all is at the forefront of consciousness - like an enormous

${ }^{9}$ See Colin McGinn, Problems in Philosophy (Oxford: Basil Blackwell, 1993), chapter 5. I should apologize for my lack of citation of theologians and philosophers of religion who have written on the topics discussed in this paper. The reason is simply that I have read very little of this literature and am not a specialist in the field.

${ }^{10}$ It is an interesting question whether God has needs - such as the need to help humanity or the need to create a universe. I think not, because that would make him vulnerable in case his needs are not met. God cannot suffer when he doesn't get what he needs. It would be quite inapt to think that God has cravings. 
Cartesian theater. ${ }^{11}$ As to dreaming, God never sleeps, so he has no opportunity to dream. And what would he dream about - his anxieties and repressed feelings? Would he have wish-fulfilment dreams in which human beings become innocent of all sin? Nor, I conjecture, does God daydream, letting his mind wander where it will. I wonder whether he has an imagination at all, in anything like the way we do, as opposed to intellectual apprehension. Does he have mental images? In what sense modality would he have them? God's mind may be considerably more capacious than ours, but it is also in certain respects simpler. ${ }^{12}$

There is much discussion as to how much of human knowledge is innate. No one doubts that we learn and acquire knowledge, so that not everything is innate, even if much knowledge may be. But God never learns anything - he certainly does not get his ideas from the world outside his mind by employing his senses. He is omniscient and always has been (there was no ignorant childhood). Thus all his knowledge is innate: it all comes from within his own nature, never being derived from what enters through the senses. Empiricism is false for God's knowledge, even if it is true for a good deal of human knowledge. Descartes thought that our innate knowledge was planted in us by God, but he would presumably not say the same about God's innate knowledge - he did not plant it in himself. For where did he get the knowledge to plant? $\mathrm{He}$ must have had it already. So God's knowledge belongs to him natively and eternally: he innately knows everything there is to know (assuming divine foreknowledge). Mathematics, logic, metaphysics, ethics, and language - this is all innate for God. And the same must be true for history, geography, cooking and so on, given his general omniscience.

I have said nothing about God's personality. The tradition sometimes ventures an opinion on this, describing God as jealous and vengeful or kindly and forgiving. God is rightly described as a person, with the attributes that define personhood (self-awareness, identity over time, reason, and so on); but it does not follow that he has a personality, and I find myself doubting the idea. It smacks of anthropomorphism,

${ }^{11}$ In fact, the idea of a divine unconscious is demonstrably impossible, because it conflicts with God's omniscience: given that God knows everything, he knows what he has in his unconscious - but then it is not unconscious.

${ }^{12}$ God doesn't suffer from conflicts, quandaries, uncertainties, cognitive dissonance, paradigm shifts, mixed emotions, and self-doubt. Nor does he endure aches and pains, troubles of the flesh. God's mind is always clear and focused, perfectly rational, never divided. 
does it not? Do we really want to entertain the possibility that God is short-tempered or softhearted or gloomy or cheerful or extraverted or introverted? The concept of personality seems not to fit the mind of God as we grasp it. The same might be said of some animals that have minds: you can have a mind, even quite a sophisticated one, and yet have no personality at all, in the usual sense. Do sheep have personalities, or snakes, or fish? Similarly, I don't think God has a personality, despite his manifest personhood. He has different desires from, say, the Devil, but that is not enough to ground the ordinary notion of personality - with the implication of quirks and arbitrariness of traits. ${ }^{13}$ That seems much too limiting, far too human. It would be odd to describe God as having a sparkling personality or as being a bit of an introvert.

Even from this quick survey, I think we can see that the project of divine psychology can yield non-trivial results. We can know quite a bit about the mind of God, even if not everything. But that limitation applies to our knowledge of the minds of terrestrial animals, including ourselves. I doubt that university departments of psychology would provide research money for a project on divine psychology, but it does seem to be a possible enterprise. It could be a branch of theology perhaps - theological psychology or psychological theology. ${ }^{14}$

\section{THE GOD-WORLD PROBLEM}

Inow want to discuss the question of the relationship between God and the world. Let us suppose God to exist and the world to exist (both existential claims could be coherently denied). By the 'world' I just mean all of spatio-temporal reality, including the minds of animals and humans. The point I wish to make is that the God-world relationship can be usefully articulated by invoking some ideas drawn from philosophy of mind.

${ }^{13}$ Typical personality traits cited by psychologists are neuroticism, extraversion, openness to experience, agreeableness, and conscientiousness. A given individual's personality corresponds to a blend of these traits, varying from one individual to the next. But none of these traits seems an apt description of God, except maybe conscientiousness. God falls at no particular point in personality space, as so defined. That is not to say that he lacks specific kinds of desire, such as the desire for good to prevail.

${ }^{14}$ A topic I have not discussed is divine memory. Does God possess a memory? Is that where God stores his vast knowledge? Does he have short-term and long-term memory? How does divine recall work? And what are God's concepts like? Does he employ family resemblance concepts, or vague concepts, or sensory concepts? Does he have a 'conceptual scheme'? 
This will act as a prelude to discussing the question of God's intervention in the world - for that question presupposes an understanding of the metaphysical relation between the two. Again, I will perforce be sketchy.

One view would be that God and the world are totally separate substances. Call the world 'empirical substance' and call God 'divine substance': then this view would be a dualism of empirical and divine substances. Such a position is modelled on the Cartesian conception of mind and body: a pair of independent substances existing alongside one another. God could exist without the world, and perhaps the world could exist without God (say, if God decided to end his own existence and leave the world intact). The two separate substances might be taken to interact or not, depending on one's metaphysical opinions. Let us suppose that they do interact, with God intervening in the course of history. There would then be a problem about how this interaction takes place, analogous to Descartes' problem of interaction. If the divine substance is non-spatial, then the problem will coincide with Descartes' problem, since mind is a non-spatial substance for him. A proponent of this interactionist dualism might propose a celestial pineal gland (the Earth!) as the locus of interaction. But this would be no better than Descartes' own 'solution', leaving the problem exactly where it was. Thus God-world substantial dualism has a classic interaction problem. It therefore seems that God will turn out to be epiphenomenal with respect to the world - which is not a happy result theologically. ${ }^{15}$

Then there is the view that God and world coincide in some way. We might here think of Spinoza's doctrine, according to which God and the world are identical. This view is analogous to the identity theory of mind and brain: not two things but one, described in two different ways. By this means we solve the problem of interaction, since we are dealing with just one spatial substance, which obeys the usual causal rules. God can cause events in the world because he is the world - parts of him are causing other parts of him, in effect. The trouble with this view is its extreme reductionism, which is tantamount to eliminativism (hence the accusation of atheism against Spinoza). If God is really nothing over and above the world, then it is hard to see what is added to the world by his existence - there may as well be no God at all. The same kind of

${ }^{15} \mathrm{I}$ am not saying there are no conceivable replies to these problems, just that both sorts of dualism run up against the same sorts of problem: God is to world as mind is to body - an extraneous entity with peculiar causal links. 
complaint has been made against identity theories of mind and brain: why speak of mind at all, if brain is all there ultimately is? All we have is a distinction of words.

The remaining views try to avoid this Scylla and Charybdis - dualism and monism - with greater or lesser success. Thus we might try the idea that God emerges from the world, and is yet something over and above the world. This view is modelled on the 'emergentist' view of mind and brain: the mind (necessarily) emerges from the brain, but what emerges is a new level of reality, not reducible to its basis in the brain. Such a position is theologically problematic, because it is hard to see how God could emerge from the world and yet be its creator (the creation relation has been inverted). But it is also metaphysically troubling, because the notion of emergence is mysterious and seemingly miraculous. How can $X$ owe its very being to $Y$ (and nothing but $Y$ ) and yet be something over and above $Y$ ? It is also not clear how the theory solves the interaction problem, once God has been granted separate ontological status as an emergent entity. We seem to be offered some sort of dual aspect view (or property dualism), and then there is a question how the extra aspect can fit into the causal order. Can't we explain everything at the $Y$ level in terms of the $Y$ aspect, with the $X$ aspect merely epiphenomenal?

Panpsychism might now be ventured: the mind is already part of the physical world in small packets, so that the emergence of mind from matter is not really radical and miraculous. Atoms have tiny bits of consciousness in them, so when they combine bigger conscious bits result. Pantheism is the analogous doctrine with regard to God: there are bits of divine dust scattered everywhere in the world, and God himself is just their universal summation. Lots of little gods get together to produce one big God, as it were. Thus the emergence of the divine from the empirical is explained - the empirical has bits of divinity in it to start with. Again, there are theological objections to this picture, with respect to creation: but we also have problems about how the combination process works, as well as the sheer implausibility of the doctrine - what exactly are these microscopic hidden gods lurking everywhere, just itching to combine into one big macroscopic God?

Lastly, we have idealism. Berkeley held that the so-called material world consists of ideas in the mind of God, so that the world is really not separate from God. There is only spiritual substance. Thus there is no Cartesian problem of interaction between substances with different essences, since there is no material substance. This is analogous to 
holding that the brain is nothing but the mind, with mind constituting the basic nature of reality. According to idealism, God never created a material universe, though he did create a universe that exists when we do not perceive it - since ideas always exist in God's mind. All causation is really mental causation, on this view, taking place within the one infinite spiritual substance, which is God. Matter is a myth invented by misguided philosophers; what we really have are ideas subsisting in the divine mind.

None of the views cited are free of difficulty, to put it mildly, either in regard to the mind or to God. There are real problem of metaphysical integration. This means that the problem of integration is not in itself a reason to reject God - any more than the analogous problem about mind and body is a reason to reject mind. In both cases, the dualist position is the one that is most immediately attractive, but it encounters serious difficulties concerning causal interaction (among other things). The other positions are attempts to resolve the interaction problem, but they suffer their own drawbacks. This is philosophy - metaphysics - at its most difficult.

\section{GOD'S AGENCY}

How does all this bear on the question of divine intervention? Let me distinguish two problems: one about interaction, the other about determinism. If we presuppose a radical dualism of God and world, then we get an interaction problem, analogous to Descartes' problem. How can God make contact with the spatio-temporal world, given that he is not himself spatio-temporal? That is indeed a problem, as it was for Descartes. We either have to declare ineradicable mystery or try to dilute the dualism. But the problem is not peculiar to God's supposed intervention in the world, since it applies also to mind-body dualism. In fact, there is an analogous problem concerning our knowledge of mathematics: how can we know about numbers, given that numbers are platonic entities existing outside of space and time? These are all real philosophical problems; the God case is not unique. Theologians can take some comfort in this fact. ${ }^{16}$

${ }^{16}$ If we follow Hume's lead on causation, we find that all causation involves intractable mystery, since we have no adequate idea of power or necessary connection. So it is not just theologians who are saddled with unfathomable causation. From this point of view, 
With respect to determinism, the problem is how it can be that God can intervene in the course of history, given that nature is governed by inviolable natural laws. Aren't all his decisions impotent to change the course of history, with the basic laws determining everything that happens? How can God hope to affect what happens in nature when nature operates by laws independently of his will? Again, this is a genuine philosophical puzzle, but it is worth observing that it applies to human decisions too. How can what we decide make any difference to the course of history, given that history is determined by laws of nature and initial conditions? How can there be 'downward causation' - from will to world? The human will looks to be epiphenomenal, with all the causal work being done by factors outside of its operations. How then is it possible for humans to intervene in nature? If we could just identify acts of will with underlying physical mechanisms, then we would not have a problem, because then decisions would be physical events in the basic causal order. But that seems too reductive - just as the analogous position with respect to God's role in history would be (God's will cannot just be an attribute of atoms, say electromagnetism). Thus we are sent on a search for some position that avoids the problems identified so far, with nothing we find proving satisfactory.

Notice that the problem is not confined to the psychological level. How can biological events, such as acts of reproduction, influence the course of history, given that physical determinism holds? Isn't everything fixed by the state of elementary particles already, so that we have no need of extra biological events to explain what happens? But then animal copulation would play no role in determining what happens - which sounds wrong. What we need is a way to reconcile downward causation with physical determinism (or indeterminism if nature is fundamentally indeterministic). This is a genuine philosophical question, to which various answers have been proposed; my point is just that the problem about God's intervention just appears to be a special case of this more general problem, and is therefore not in itself a reason for theological anxiety. How can animal action intervene in the causal order, if it is governed from the ground up by physics? How can divine action intervene in the causal order, if it is governed from the ground up by physics? We surely don't want to accept that God or animals need to

divine causal intervention is not much worse than gravity, which is also (as Newton admitted) 'occult'. 
thwart the laws of physics in order to have an influence on what happens, but then it seems that all the causation in the universe proceeds purely from atoms and their laws. As I say, this is a real philosophical puzzle; but it is a general puzzle about causation and the entities that populate the universe whose antics make a difference to what happens. It is not clear that the problem of divine intervention in a law-governed world adds anything new or unique.

As to the very different idea that God can intervene in nature in such a way as to disrupt its laws, I hold to the orthodox opinion that no such thing has ever occurred. There is simply no good evidence that such a 'miracle' has ever been observed. What is commonly advanced as evidence is just so much questionable testimony, to which Hume's classic argument applies. ${ }^{17}$ The kind of event that would constitute such a breach of natural laws would be the suspension of the law of gravity as someone is plummeting to earth, resulting in their ceasing to fall and floating in thin air. The forces of nature would need to be countermanded by God for that to happen. Even if God has such a power, conferred by his omnipotence, I don't believe he has ever exercised it; and the idea that he does it sparingly and sporadically, for especially good ends, raises the obvious question of why he doesn't do it more often. By contrast, the question of the compatibility of divine intervention and the unbroken existence of natural laws raises a genuine conceptual puzzle; but, as I have said, the puzzle is not confined to God's action in the world.

As a final remark, let me just say that a radically dualist view of the relationship between God and the universe is apt to make the problem of intervention more difficult than under other metaphysical conceptions. It is the same with Descartes' dualism: radical separation makes the mind cut off from the causal network in a way it is intuitively not cut off. We need to find a closer relationship than this if the causal picture is to work. Philosophers have toyed with notions like 'realization' as a way to characterize the relationship between the mental level and the physical level, so that the levels are close enough to make causal sense. The model here would be, say, the way an eye is realized in different anatomical

${ }_{17}$ Namely, we always have more reason to doubt the testimony than to believe in the miracle. In order to overturn this principle in a particular case we would need a lot of very credible testimony, based on solid observation; and that we never seem to find. This Humean point does not show that miracles are impossible, which is a metaphysical claim; it merely shows that it is difficult to get good evidence for miracles, which is an epistemological claim. 
organs: being an eye is not identical to any one anatomical type of eye, yet we can say that eyes are 'realized' by different anatomical types. If we take our lead from this example, then we could try saying that God is realized by the universe, without being reducible to the universe. He has no further substance over and above that of the universe, but he is not simply identical to the universe (I suppose this would qualify as a type of pantheism). It is a bit like the way a statue is realized in a particular chunk of bronze, without being strictly identical a chunk of bronze. ${ }^{18}$ I am not sure I know what this idea of realization comes to for the case of God and the universe, but it least it promises to make it feasible for God to be enmeshed in the natural causal order, without collapsing into it. It is not so much that God intervenes as supervenes, to use the jargon. On this picture, there is a mega-universe that includes both the physical universe and God, with the two locked somehow together. But trying to make sense of this is a tall order.

${ }^{18}$ The classic argument against the identity of statue and chunk of bronze is based on Leibniz's law: the chunk existed before the statue did and persists when the statue is gone, so the two do not have all their properties in common. 